Rozalia Sasor (D) Uniwersytet Jagielloński rozalia.kosmider-sasor@uj.edu.pl

\title{
Odmiana imion i nazwisk katalońskich w języku polskim
}

\begin{abstract}
Abstrakt
Tematem artykułu jest problem odmiany imion i nazwisk katalońskich w języku polskim, który do tej pory nie został nigdzie kompleksowo opracowany. Starając się zapełnić tę lukę, Autorka proponuje usystematyzowany zestaw reguł odmiany imion i nazwisk opracowany na podstawie zasad obowiązujących w języku polskim z uwzględnieniem reguł szczegółowych odnoszących się do odmiany nazw własnych w językach hiszpańskim, włoskim, francuskim i węgierskim. W zestawie przedstawiono polskie wzorce fleksyjne katalońskich imion i nazwisk żeńskich i męskich dla liczby pojedynczej oraz mnogiej.

Słowa kluczowe: nazwy własne, imiona i nazwiska katalońskie, odmiana imion i nazwisk

Abstract

Inflection of Catalan Given Names and Surnames in the Polish Language The problem discussed in this article is the inflection of Catalan given names and surnames in the Polish language, which has never been fully resolved. In order to fill that gap, author proposes systematic set of rules concerning the inflection of given names and surnames. It is based on the Polish grammar rules, but in relation to the detailed rules of how the proper names are inflected in Spanish, Italian, French, and Hungarian. The proposed solution contains the inflectional Polish
\end{abstract}


paradigm for the Catalan masculine and feminine given names and surnames both in singular and plural.

Keywords: proper names, Catalan given names and surnames, inflection of given names and surnames

Konieczność uregulowania zapisu imion i nazwisk katalońskich podyktowana jest brakiem sformalizowanych zasad odmiany katalońskich nazw własnych w języku polskim, mimo że ich obecność w polszczyźnie jest coraz bardziej widoczna. Z jednej strony aktywne dążenia niepodległościowe regionu i związane z nimi wstrząsy polityczne zwróciły uwagę mediów na relacje hiszpańskiego rządu centralnego z katalońską wspólnotą autonomiczną. Z drugiej zaś działalność związanego z katalońskim rządem Instytutu Ramona Llulla, który oferuje wydawcom liczne granty na tłumaczenie i promocję literatury katalońskojęzycznej za granicą, przekłada się na wzrost liczby publikowanych w Polsce książek tłumaczonych z języka katalońskiego. Zatem siłą rzeczy zarówno w tekstach prasowych, jak i w literaturze pięknej pojawiają się imiona i nazwiska czy to postaci współczesnych, czy historycznych, czy też fikcyjnych wpisujących się w tradycję języka katalońskiego. Jednak niemożność skonsultowania poprawności form fleksyjnych z jakimkolwiek źródłem normatywnym przedstawiającym zbiorczo reguły odmiany dla języka katalońskiego skutkuje rozmaitością, nieraz wyjątkowo barwną, rozwiązań proponowanych przez dziennikarzy, tłumaczy i redaktorów, a nawet świat akademicki. I w efekcie prowadzi do chaosu językowego ${ }^{1}$. Celem niniejszego artykułu jest zatem próba poskromienia owego chaosu i zaproponowanie zasad odmiany katalońskich imion i nazwisk w sposób uporządkowany oraz czytelny również dla osób, które języka katalońskiego nie znają.

Ze względu na wspomniany wyżej cel artykułu oraz jego praktyczny charakter zdecydowałam się na pominięcie szczegółowego

${ }^{1} \mathrm{Na}$ trudności z doborem właściwych form fleksyjnych dla imion i nazwisk obcych (a także wiele innych aspektów wzorca odmiany nazwisk obcych) zwracali już uwagę Izabela i Jerzy Bartmińscy w pracy Nazwiska obce w języku polskim (1978), PWN, Warszawa. 
wprowadzenia metodologicznego w zakresie językoznawstwa normatywnego, ograniczając się do wyłożenia tez podstawowych dla powstania omówionego niżej zestawu reguł. Zbiór wzorów odmiany katalońskich imion i nazwisk zbudowałam, wychodząc od systemu języka polskiego w rozumieniu Andrzeja Markowskiego (2005: 2123), to jest właściwych dla naszego języka modeli czy potencji języka realizowanych przez normę oraz skodyfikowanych już i funkcjonujących w obrębie tej ostatniej zasad. Tym niemniej, ponieważ w niektórych przypadkach istnieje wyraźna tendencja do odchodzenia przez użytkowników języka od ustalonego wzorca, biorę również pod uwagę koncepcję dwóch poziomów normy, obejmujących zarówno normę wzorcową, jak i użytkową (Markowski, 2005: 32-34). Norma wzorcowa stanowi ramę dla zaproponowanych reguł odmiany, natomiast użytkowa dopuszcza jako poprawną pewną wariantywność form. Dla przykładu, imiona męskie zakończone na -e zgodnie z normą wzorcową nie powinny być odmieniane, jednak norma użytkowa, czyli zwyczaj językowy odmieniania ich zgodnie z wzorcem deklinacji nazwisk, pozwala na uznanie wariantu odmienionego za dopuszczalny.

Przy wyborze modelu deklinacyjnego dla imion i nazwisk kierowałam się, zgodnie z przyjętymi w języku polskim zasadami (Jadacka, 2005: 50), ich postacią brzmieniową, nie graficzną. W większości przypadków polski użytkownik języka nie będzie mieć problemów z samodzielnym dobraniem odpowiedniego modelu, ponieważ język kataloński jest językiem fonetycznym. Niemniej w kilku przypadkach zachodzą różnice między zapisem a wymową, które wyjaśniam, podając właściwy model fleksyjny. W tym miejscu warto zwrócić uwagę na wymowę wybranych katalońskich digrafów, które, jeśli znajdują się na końcu wyrazu, mają istotne znaczenie dla ustalenia właściwego wzorca odmiany ${ }^{2}$. I tak, digraf -ig wymawiamy [dź], jak w nazwisku Puig [Pudź]; -ix [isz] jak Foix [Foisz]; -ny [ń] jak Fortuny [Fortuń]; -ch [k], ponieważ -h jest nieme, jak Bosch [Bosk]; w dwuznakach -nt i -lt, jeśli występują na końcu wyrazu, nieme jest -t, jak Queralt [Keral].

${ }^{2}$ Zasady wymowy na podstawie Gramàtica de la llengua catalana, 2016, s. 59-61, 67. 
W dwóch ostatnich przypadkach, to jest gdy nazwisko kończy się na niewymawianą spółgłoskę, oddzielamy jego pisaną formę od polskiej końcówki fleksyjnej apostrofem (Jadacka, 2005: 51).

Wzory odmiany zostały opracowane dla bazy materiałowej zebranej z następujących źródeł: imiona i nazwiska osób publicznych, historycznych i współczesnych, takich jak pisarki i pisarze czy polityczki i politycy; bazy danych i spisy imion i nazwisk katalońskich, zwłaszcza te udostępniane przez Societat Catalana de Genealogia, Societat d'Onomàstica, Gabinet d'Estudis Socials i Opinió Pública oraz Institut d'Estadística de Catalunya, strona internetowa Noms del Món z propozycjami imion katalońskich dla dzieci oraz strona projektu Cognoms Catalans realizowanego w Instytucie Biologii Ewolucyjnej Uniwersytetu Pompeu Fabra (Barcelona). Pomocą w ustaleniu bazy materiałowej był również artykuł Francesca Calafella Majó „Els noms del catalans del segle XXI", opublikowany w czasopiśmie Paratge (2013: 159-176).

\section{Odmiana imion}

Zgodnie z zasadami pisowni imion obcych podanymi przez Słownik języka polskiego PWN (reguła nr [238] 60.3): „Imiona osób nam współczesnych powinniśmy pisać w oryginalnej postaci graficznej, nawet wówczas, gdy te imiona mają polskie odpowiedniki”, czyli w odniesieniu do imion katalońskich powinniśmy się posługiwać formami Mercè, Pere czy Jaume, nie zaś Merceda, Piotr czy Jakub. Jednak zarówno praktyka językowa, jak i otwarta forma przytoczonej wyżej reguły pokazują, że nie jest ona tak łatwa do zastosowania, jak by się na pierwszy rzut oka wydawało. Przeanalizujmy zatem jej najważniejsze części składowe.

Po pierwsze, co to znaczy „osób nam współczesnych”? Chociaż reguła 60.3 z założenia odnosi się do ,imion żyjących ${ }^{3}$ współcześnie osób narodowości innych niż polska", to obejmuje ona również osoby

3 Jeśli nie zaznaczono inaczej, wszystkie podkreślenia pochodzą od Autorki artykułu. 
nieżyjące, ponieważ wyznacznikiem ich współczesności nie jest data śmierci, lecz okres działalności. Ponadto, wskazując na wyjątki od swojego zastosowania, wymienia osoby, ,które działały lub rozpoczęły działalność przed XX wiekiem”. Stąd możemy przyjąć, że osoby współczesne to takie, które działały lub rozpoczęły działalność w wieku XX, czyli tym samym współczesność obejmuje nie tylko naszą teraźniejszość, to jest wiek XXI, ale również ubiegłe stulecie.

Po drugie, dlaczego tylko powinniśmy, a nie musimy? Otóż zasady zapisywania imion oraz nazwisk obcych nie są w języku polskim do końca uregulowane i chociaż istnieją pewne normy ogólne, to nie można zapominać o licznych wyjątkach, które funkcjonują na zasadzie zwyczaju językowego. Wspomniana wyżej reguła 60.3 podaje przykład Thomasa Manna - choć z zasady powinniśmy zapisywać jego imię w oryginalnej postaci graficznej, jest przecież pisarzem XX-wiecznym, to w polszczyźnie funkcjonuje również grafia Tomasz Mann, uznawana za równie poprawną, jak oryginalna. Tym niemniej wydaje się, że w przypadku osób należących do kręgu kultury i języka katalońskiego istnieją jedynie dwa przypadki postaci cieszących się tak dużym uznaniem, by ich sława dotarła do Polski i doprowadziła do powstania spolszczonej, powszechnie funkcjonującej grafii nazwiska. Chodzi rzecz jasna o malarza Salvadora (lub Salwadora) Dalego (w katalońskim oryginale Salvador Dali) i architekta Antonia Gaudiego (kat. Antoni Gaudi). Co ciekawe, chociaż Stownik... PWN przestrzega przed łączeniem imienia w grafii oryginalnej ze spolszczonym nazwiskiem, to takie właśnie formy w obydwu wymienionych wyżej przypadkach przyjęły się w naszym języku i takie uznawane są za poprawne. Można zatem przyjąć, że w odniesieniu do imion i nazwisk katalońskich częściej musimy, niż powinniśmy, posługiwać się oryginalnym zapisem, choć oczywiście może się zdarzyć, że do czasu przyjęcia zaproponowanych norm jakaś jeszcze osoba zostanie uhonorowana spolszczoną formą swojego nazwiska.

Po trzecie i ostatnie, reguła 60.3 zobowiązuje do zapisywania imion i nazwisk obcych w oryginalnej postaci graficznej, czyli w przypadku języka katalońskiego z zachowaniem znaków diakrytycznych oznaczających akcenty. Słownik... PWN nie precyzuje, czy również 
w formach przypadkowych rzeczownika, ale - wbrew temu, co sugerują niektóre polskie wydawnictwa - kwestia wydaje się jasna. Z każdej formy przypadkowej powinno się dać wyprowadzić formę podstawową rzeczownika, to jest jego mianownik. Jeśli usuniemy w odmianie oznaczenia akcentów, uniemożliwimy tym samym ustalenie prawidłowej formy mianownika odmienianego nazwiska. Mimo że przywołane wyżej spolszczenia nazwisk Dalí oraz Gaudí utraciły oryginalne znaki diakrytyczne (Dalego, Gaudiego), to już w przypadku popularnego w Polsce katalońskiego pisarza Jaumego Cabré formy fleksyjne nazwiska winny zachować oznaczenie akcentu, to jest Cabrégo, Cabrému itd.

O ile w odniesieniu do osób działających współcześnie stosowanie reguły 60.3 nie nastręcza w zasadzie większych problemów, o tyle w stosunku do postaci historycznych, to jest działających przed XX wiekiem, musimy zdać się na zwyczaj językowy. To znaczy imiona i przydomki takich postaci spolszczamy, ale tylko jeśli mają swoje odpowiedniki w języku polskim i istnieje taki zwyczaj. Czyli innymi słowy - będziemy spolszczać imiona władców, posługując się czy to polskim ekwiwalentem thumaczeniowym (np. w przypadku przydomków), czy też polskim odpowiednikiem imienia, ale już niekoniecznie pisarzy, malarzy czy przedstawicieli Kościoła. Dla przykładu, w języku polskim za poprawną formę imienia króla Korony Aragonii panującego w latach 1396-1410 przyjmiemy zapis Marcin I Ludzki, a nie Martí I el Humà. Natomiast imię franciszkańskiego autora działającego w tym samym okresie podamy w formie oryginalnej, czyli Francesc Eiximenis. Od przywołanej wyżej zasady istnieją rzecz jasna wyjątki dotyczące osób, które zdążyły zaistnieć w polskim piśmiennictwie, nawet jeśli tylko epizodycznie. Należą do nich majorkański filozof Ramon Llull (1232-1316), walencki dominikanin Vicent Ferrer (1350-1419) oraz lekarz i alchemik, prawdopodobnie również pochodzący z regionu Walencji, Arnau de Vilanova (1240/1258-1311/1313). W odniesieniu do tych postaci można posługiwać się aż trzema formami zapisu, to jest oryginalną katalońską, łacińską lub spolszczoną (przeważnie tworzoną na bazie formy łacińskiej, nie zaś oryginalnej), 
przy czym przywołanie formy łacińskiej powinno mieć uzasadnienie w tekście:

- (kat.) Ramon Llull; (łac.) Raimundus Lullus; (pl.) Rajmund Lull. Zapis łączący spolszczone imię z oryginalnym nazwiskiem, czyli *Rajmund Llull należy uznać za nieprawidłowy.

- (kat.) Vicent Ferrer; (łac.) Vincentius Ferrerius; (pl.) Wincenty Ferreriusz.

- (kat.) Arnau de Vilanova; (łac.) Arnaldus de Villa Nova lub Arnaldus Villanovanus; (p1.) Arnold de Vilanova.

Należy również pamiętać, że posługiwanie się hiszpańską postacią graficzną imion osób należących do kultury języka katalońskiego, jak np. *Franscisco Eiximenis czy *Vincent Ferrer, nie tylko jest niezgodne z normami językowymi, ale również świadczy o niepełnej znajomości realiów językowych i historycznych regionów katalońskojęzycznych stanowiących dziś część Hiszpanii. Język kataloński należy do rodziny języków romańskich i jako taki posiada pewne cechy wspólne z hiszpańskim, tym niemniej nie można zastępować występujących w nim nazw własnych odpowiednikami kastylijskimi, usprawiedliwiając decyzję przynależnością administracyjną Katalonii do Hiszpanii. Nie można też stosować w odmianie katalońskich nazw własnych reguł dotyczących języka hiszpańskiego, choćby ze względu na różne zasady wymowy obowiązujące w każdym z języków. Poniżej przedstawiam szczegółowe omówienie konkretnych przypadków odmiany imion męskich i żeńskich, a także nazwisk katalońskich, $\mathrm{w}$ formach dla liczby pojedynczej oraz mnogiej. Zgodnie z zasadami języka polskiego za podstawę odmiany imion oraz nazwisk przyjmuję wzorzec odmiany wyrazów pospolitych o podobnych brzmieniowo zakończeniach, biorąc pod uwagę końcówkę w wymowie.

\subsection{Imiona żeńskie}

W odniesieniu do imion żeńskich stosujemy następujące zasady (Stownik... PWN, reguła nr [240] 61.2): 
1. Odmieniają się wszystkie imiona żeńskie zakończone w wymowie na samogłoskę -a, np. Júlia [Żulia] (Júlii, Júlii, Júlię, z Júlią, o Júlii, W. Júlio), Dolça [Dolsa] (Dolçy, Dolçie, Dolçę, z Dolça, o Dolçie, W. Dolço), Ariadna (jak Dolça). W liczbie mnogiej wzorzec odmiany mogą stanowić imiona polskie o podobnym brzmieniu, np. Julia, lub rzeczowniki pospolite, np. kosa dla Dolça, czyli dwie Júlie, Dolçy czy Ariadny.

2. Pozostałe imiona żeńskie się nie odmieniają. Czyli imiona zakończone na -o (Ailo), -u (Beatriu), -e (Carme [Karme], Irene), a także samogłoskę akcentowaną (Mercè, Noemi) i na spółgłoskę (Almodis, Dolors, Neus, Àngels, Meritxell) nie zmieniają postaci niezależnie od wymowy z braku analogicznych wzorców deklinacyjnych w polszczyźnie.

\subsection{Imiona męskie}

W odniesieniu do imion męskich bierzemy pod uwagę ich zakończenie w wymowie. Obowiązująca w języku polskim zasada (wskazana w poprzednim punkcie) nakazuje odmieniać imiona zakończone na spółgłoskę oraz samogłoski -a, -o, -y oraz -i. Natomiast imiona męskie zakończone na -e oraz -é zasadniczo powinny pozostawać w formie nieodmiennej, jednak Stownik... PWN podaje jednocześnie, że: „Można też odmieniać imiona zakończone na $-e,-h$ nieme następujące po samogłosce oraz akcentowane na ostatniej sylabie" (Slownik... PWN, reguła nr [240] 61.2). Podobnie do kwestii odmiany imion zakończonych na -e oraz -é podchodzi Jana Grzenia udzielający porad w Poradni Językowej PWN, gdzie powołuje się na zwyczaj językowy $i$ tendencję do odmieniania imion zgodnie ze wzorcem odmiany nazwisk ${ }^{4}$. Dlatego dla takich imion, jak Pere czy Jaume można przyjąć dwie formy zapisu:

4 Por. Poradnia Językowa PWN, J. Grzenia (2002), „Imiona i nazwiska hiszpańskie", [on-line] https://sjp.pwn.pl/poradnia/haslo/imiona-i-nazwiska- hiszpanskie;2126.html - 21.02.2021; (2011), „Odmiana imion na -e”, [on-line] https://sjp.pwn.pl/poradnia/haslo/odmiana-imion-na-e;12497.html - 21.02.2021; (2013), „Imiona portugalskie”, [on-line] https://sjp.pwn.pl/poradnia/haslo/ 
- Pere (Perego, Peremu, Perego, z/o Perem, W. Pere albo ndm);

- Jaume [Żaume] (Jaumego, Jaumemu, Jaumego, z/o Jaumem, W. Jaume albo ndm);

- Guifré [Gifre] (Guifrégo, Guifrému, Guifrégo, z/o Guifrém, W. Guifré albo ndm).

Ponieważ w języku katalońskim nie istnieją oryginalne imiona męskie zakończone na -o lub -y, a te, które funkcjonują, pochodzą z innych języków i należy je odmieniać zgodnie z właściwymi dla nich zasadami, przedstawię jedynie odmianę katalońskich imion męskich zakończonych na spółgłoskę oraz samogłoski -a, - à, -i oraz -í:

1. Imiona zakończone na spółgłoskę, jak np. Xavier, Oriol [Uriol], Marc [Mark], Biel, Pep, Quim [Kim], Jesús [Żezus] czy Cèsar [Sezar], odmieniają się zgodnie ze wzorcami rzeczowników pospolitych, i tak: Oriol (Oriola, Oriolowi, Oriola, z Oriolem, o Oriolu, W. Oriolu), Jesús (Jesúsa, Jesúsowi, Jesúsa, z Jesúsem, o Jesúsie, W. Jesúsie) oraz Cèsar (Cèsara, Cèsarowi, Cèsara, z Cèsarem, o Cèsarze, W. Cèsarze). W liczbie mnogiej imiona te przyjmą formę zgodną ze wzorcem odmiany rzeczowników męskoosobowych: dwaj Oriolowie, Jesúsowie, Cèsarowie; dwóch Oriolów, Jesúsów, Cèsarów itd.

2. Odmieniają się również imiona zakończone na samogłoskę -a, jak np. Borja [Borża] (Borjy, Borjy, Borje, z Borja, o Borjy, W. Borjo), przyjmując w liczbie mnogiej formę Borjowie (Borjów itd.). Natomiast imiona męskie zakończone na -à (-a akcentowane) pozostają nieodmienne, np. Adrià, Damià. Wprawdzie zgodnie z regułą 61.2 można je odmieniać (przy czym trudno znaleźć łatwy do zastosowania wzorzec), ale jednak należy pamiętać, że w odmianie znika -à, co uniemożliwia odtworzenie z form fleksyjnych formy mianownika.

imiona-portugalskie;14244.html - 21.02.2021 i inne. Analiza wymienionych porad wskazuje na wyraźną tendencję do odmiany imion męskich zakończonych na -e, a także wzrost akceptacji dla tego zwyczaju nie tylko wśród użytkowników języka, ale również językoznawców. 
3. Imiona zakończone na samogłoskę -i, jak np. Ignasi [Ignazi], Ovi$d i$ [Uwidi], odmieniają się zgodnie z deklinacją przymiotnikową według wzoru: Ovidi (Ovidiego, Ovidiemu, Ovidiego, z/o Ovidim, W. Ovidi), a w liczbie mnogiej: Ovidiowie (Ovidich, Ovidim, Ovidich, z Ovidimi, o Ovidich, W. Ovidiowie). Inaczej niż w przypadku imion zakończonych na -a akcentowane, imiona zakończone na akcentowane -i, np. Martí, Sadurní, również będą się odmieniać, ponieważ w formach przypadkowych zachowana jest w temacie forma mianownikowa imienia. Należy przy tym pamiętać, że w odmianie zachowujemy oryginalną postać graficzną imienia, czyli zaznaczamy akcent nad -í.

\section{Odmiana nazwisk}

Podobnie jak w przypadku nazwisk hiszpańskich, również nazwiska katalońskie nie wskazują na płeć właściciela. Jednak zgodnie z zasadami obowiązującymi w języku polskim ,jeśli tylko jest możliwe przyporządkowanie nazwiska jakiemuś wzorcowi odmiany, należy je odmieniać. Wybór odpowiedniego wzorca odmiany zależy głównie od:

- płci właściciela,

- jego narodowości,

- zakończenia nazwiska (może chodzić albo o zakończenie fonetycznej formy nazwiska, albo o zakończenie tematu)" (Stownik... PWN, reguła nr 62).

Odmieniając nazwiska katalońskie, należy brać pod uwagę ich zakończenie w wymowie, a zwłaszcza zwracać uwagę na nieme - $\mathrm{h}$, jak w nazwisku March [Mark], oraz nieme -t w występujących na końcu wyrazu złożeniach -nt i -lt, jak w nazwisku Puigdemont [Pudźdemon].

\subsection{Nazwiska żeńskie}

Mimo że, jak wspomniano, katalońskie nazwiska nie wskazują na płeć, to w tłumaczeniu na język polski należy ją uwzględnić. Zgodnie z regułą nr [241] 63 podaną w „Zasadach pisowni i interpunkcji” Słowni$k a$... PWN odmieniać się będą wyłącznie nazwiska kobiet zakończone 
na -a, według wzoru odmiany rzeczowników pospolitych o podobnym zakończeniu, np. Torra jak 'komora' lub 'mirra': Maria Torra (Marii Torry, Marii Torze, Marię Torrę, z Maria Torra, o Marii Torze, W. Mario Torro); Borja [Borża] jak 'komża', 'oberża': (Borjy, Borjy, Borję, z Borja, o Borjy, W. Borjo); Vilagrasa [Bilagraza] jak 'skaza' (Vilagrasy, Vilagrasie, Vilagrase, z Vilagrasa, o Vilagrasie, W. Vilagraso); Vilallonga [Bilalionga] jak 'ranga', 'klinga' (Vilallongi, Vilallondze, Vilallonge, z Vilallonga, o Vilallondze, W. Vilallongo). Również formy liczby mnogiej tworzymy, biorąc za wzorzec formy odmiany rzeczowników pospolitych dla liczby mnogiej. Pozostałe nazwiska, jeśli są noszone przez kobiety, się nie odmieniają.

\subsection{Nazwiska męskie}

Zasady odnoszące się do odmiany nazwisk noszonych przez mężczyzn charakteryzuje ,znaczny stopień trudności tego problemu językowego" (Stownik... PWN, reguła nr 64). Nazwiska, w zależności od narodowości osoby je noszącej oraz brzmienia, mogą przyjmować różne formy fleksyjne, a niektóre można pozostawić również nieodmienione, o ile zostały poprzedzone imieniem lub rzeczownikiem pospolitym, jak np. 'pan', 'prezydent'. Dotyczy to zwłaszcza nazwisk zakończonych na -e, -o oraz tych akcentowanych na ostatniej sylabie, jak np. pan Cabré (z panem Cabré).

Ponieważ dla nazwisk katalońskich nie zostały ustalone osobne zasady, a różnorodność ich form utrudnia dostosowanie do wzorców odmiany już istniejących, proponuję następujący zestaw reguł bazujący na wzorcach odmiany nazwisk francuskich, włoskich i węgierskich:

1. We wszystkich formach przypadkowych należy zachować oryginalną postać graficzną nazwiska, to jest znak akcentu, oprócz sytuacji, w których brzmienie głoski kończącej temat nazwiska w odmianie jest inne niż w oryginale, np. Domenèch, o Domenèch'u, ale Torra, o Torze.

${ }^{5}$ Nazwisko Borja - noszone m.in. przez papieża Aleksandra VI pochodzącego z Xàtivy w regionie Walencji - znane jest w Polsce w zitalianizowanej formie Borgia. 
2. W niektórych nazwiskach katalońskich pojawia się -h nieme, jak np. March [Mark], Bosch [Bosk], Llach [Liak] czy Domenèch [Dumenek]. W odmianie takie nazwiska otrzymują polskie końcówki po apostrofie: March'a [Marka], March'owi [Markowi], March'a [Marka], z March 'iem [Markiem], o March'u [Marku], W. March'u [Marku]; oraz w liczbie mnogiej: March'owie [Markowie], March'ów [Marków] itd. Podobnie z apostrofem należy zapisywać nazwiska zakończone na -nt i -lt, ponieważ występujące w nich -t jest nieme. Dlatego prawidłowa odmiana nazwiska Puigdemont [Pudźdemon] powinna wyglądać następująco: Puigdemont'a [Pudźdemona], Puigdemont'owi [Pudźdemonowi], Puigdemont'a [Pudźdemona], z Puigdemont'em [Pudźdemonem], o Puigdemont 'ie [Pudźdemonie], W. Puigdemont'ie; oraz w liczbie mnogiej: Puigdemont'owie [Pudźdemonowie], Puigdemont'ów [Pudźdemonów] i dalej zgodnie ze wzorcem odmiany wyrazu 'pan'. Tak samo nazwisko Queralt [Keral] zarówno w liczbie pojedynczej, jak i mnogiej przyjmie w odmianie formy z apostrofem: Queralt'a [Kerala], z Queralt'em [Keralem], Queralt'owie [Keralowie].

3. Odrębnym i dość trudnym przypadkiem są nazwiska zakończone na -ny wymawiane jak polskie -ń, np. Veny [Beń] czy Alemany [Alemań], ponieważ, aby znaleźć wzorzec ich odmiany, trzeba sięgnąć do zasad regulujących budowanie form fleksyjnych nazwisk węgierskich zakończonych na -ny, takich jak Arany [Arań]. Nazwiska te odmieniają się jak rzeczowniki pospolite o podobnym zakończeniu, czyli np. 'koń', 'więzień'. Zatem prawidłowe formy odmiany nazwiska Alemany będą wyglądać następująco: Alemanya [Alemańa], Alemanyowi [Alemańowi], z Alemanyem [Alemańem], o Alemanyu [Alemańu], W. Alemanyu [Alemańu]. W liczbie mnogiej, w mianowniku i wołaczu, formy przyjmują końcówki właściwe dla rzeczowników w rodzaju męskoosobowym.

4. Natomiast nazwiska zakończone na każdą inną spółgłoskę otrzymują końcówki polskie bez apostrofu, np. Mas (Masa, z Masem, o Masie) czy Casals, Ferrer (Ferrera, z Ferrerem, o Ferrerze), Puig [Pudź] (Puiga, z Puigem, o Puigu), Vidal (Vidala, z Vidalem, 
o Vidalu), Foix [Foisz] (Foixa, z Foixem, o Foixu), natomiast w liczbie mnogiej odmieniają się zgodnie ze wzorcem dla rzeczowników w rodzaju męskoosobowym.

5. Nazwiska męskie zakończone na samogłoskę -a odmieniają się według wzoru odmiany rzeczowników pospolitych o podobnym zakończeniu, to jest Roca [Roka] jak 'foka' (Roki ${ }^{6}$, Roce, Roce [Rokę], z Roca [Roka]], o Roce, W. Roco [Roko]), a Riera jak 'kariera' (Riery, z Riera, o Rierze). W liczbie mnogiej nazwiska takie przyjmą w mianowniku i wołaczu końcówkę -owie (Rocowie [Rokowie], Rierowie), w dopełniczu i bierniku -ów (Roców [Roków], Rierów), w celowniku (Rocom [Rokom], Rierom), w narzędniku (Rocami [Rokami], Rierami) i miejscowniku (Rocach [Rokach], Rierach). Tym niemniej nazwiska zakończone na -à, to jest akcentowane na ostatnią sylabę, pozostają nieodmienne, np. Francesc Macià [Fransesk Masia] (Francesca Macià [Franseska Masia]) ze względu na brak pasującego wzorca odmiany.

6. Występujące w Katalonii nazwiska zakończone na samogłoskę -o to zwykle nazwiska hiszpańskie i odmieniają się zgodnie ze wzorcem dla takich nazwisk ${ }^{7}$, czyli jak rzeczowniki męskie, jednak tylko wtedy, kiedy formy fleksyjne pozwalają na odtworzenie formy mianownika, np. Calvo [Kalbo] (Calva, Calvowi, Calva, z Calvem, o Calvie, W. Calvo). Przeważnie jednak pozostają nieodmienione, zwłaszcza jeśli są krótkie. Podobnie męskie nazwiska katalońskie zakończone na -ó, np. Monzó, Cantó, Furió, to jest akcentowane na ostatnią sylabę, pozostają nieodmienne $\mathrm{z}$ braku pasującego wzorca odmiany.

7. Nazwiska zakończone na samogłoskę -u odmieniają się jak rzeczowniki pospolite o podobnym zakończeniu, np. Grau jak 'konował' (Grana, Granowi, Grana, z Grauem, ale o Grau (sic!), W. Grale). Wariantywna forma miejscownika, to jest Grale, jest

${ }^{6}$ Zmiana 'c' na 'k' jest wynikiem pojawienia się w odmianie miękkiego [k], czyli [k'].

${ }^{7}$ Por. A. Nowakowska-Głuszek (2016), „Hiszpańskie imiona i nazwiska w thumaczeniu poświadczonym na język polski”, Comparative Legilinguistics, 25, s. 91 . 
zgodna z regułą nr 66.3 Stownika... PWN, którą dostosowuję do języka katalońskiego: „Jeśli w którymś przypadku gramatycznym brzmienie głoski kończącej temat nazwiska angielskiego lub francuskiego jest w języku polskim inne niż w języku oryginalnym, wówczas zakończenie tego nazwiska piszemy zgodnie z pisownią polską", np. Barthes [Bart], z Barthes 'em, o Barcie. Tym niemniej ze względu na deformację oryginalnej głoski w formie miejscownika, gdzie -u przechodzi w -1, i tym samym niemożność wyprowadzenia z zapisu formy podstawowej, należy uznać za poprawną formę nieodmienną, jak dla nazwiska Turnau, i odwołać się do reguły 67.4 Słownika ... PWN, dostosowawszy ją do języka katalońskiego, to jest: „Nazwiska niemieckie zakończone na -au odmieniają się jak rzeczowniki męskie (np. admirat); w miejscowniku nie odmieniają się" (Cieślikowa, 2002: 59; SJP PWN).

a. Wyjątek stanowią tu nazwiska zakończone na -iu, takie jak Espriu, które pozostają nieodmienne z braku pasującego wzorca odmiany.

8. Nazwiska zakończone na samogłoskę -i oraz -í odmieniają się jak nazwiska włoskie, francuskie czy angielskie zakończone w wymowie na tę samą głoskę, czyli jak polskie przymiotniki, np. Albi (Albiego, Albiemu, Albiego, z Albim, o Albim, W. Albi) oraz Martí (Martiego, Martiemu, Martíego, z Martím, o Martím, W. Martí). W przypadku nazwisk zakończonych na -í istnieje również możliwość pozostawienie ich w formie nieodmienionej, o ile zostały poprzedzone imieniem lub rzeczownikiem pospolitym. Natomiast nazwiska Dali oraz Gaudi funkcjonują w naszym języku w formie spolszczonej: Dali, Gaudi i odmieniają się według wzoru Dalego, Dalemu itd. oraz Gaudiego, Gaudiemu itd.

9. Nazwiska zakończone na samogłoskę -e oraz -é odmieniają się jak polskie przymiotniki, np. Bonastre (Bonastrego, Bonastremu, Bonastrego, z Bonastrem, o Bonastrem, W. Bonastre) czy Batlle, a także Cabré (Cabrégo, Cabrému, Cabrégo, z Cabrém, o Cabrém, W. Cabré). Te ostatnie, to jest nazwiska zakończone na -é, jak wspomniane Cabré czy Farré, mogą pozostać nieodmienne, o ile zostały poprzedzone imieniem lub rzeczownikiem pospolitym, np. 
wypowiedź pana Cabré. Osobnym, nastręczającym pewne trudności problemem jest odmiana zestawień składających się z imienia i nazwiska zakończonych na -e lub -é, gdzie mamy kilka możliwości: twórczość Jaume Cabrégo lub twórczość Jaumego Cabré.

Jak można się przekonać na podstawie podanej wyżej propozycji wzorców, odmiana imion i nazwisk katalońskich w języku polskim nie jest prosta, a często nastręcza wielu trudności, zwłaszcza osobom, które nie znają języka katalońskiego i obowiązujących w nim zasad wymowy. Zwłaszcza w przypadkach dla polskiego użytkownika języka nieoczywistych, np. gdy nazwisko kończy się na niewymawiane -h lub -t, można znaleźć liczne przykłady nieprawidłowej odmiany, jak choćby *Do Komitetu Praw Człowieka ONZ trafiła skarga byłego premiera Katalonii Carlesa Puigdemonta przeciwko Hiszpanii (DGP, 27.03.2018) czy *Poezja Ausiasa Marcha (1397-1459) i romans rycerski Joanota Martorella (Komorowski, 2019). Nadto prawidłowe posługiwanie się formami fleksyjnymi wymaga nie tylko konsultowania reguł opisanych choćby w ,Zasadach pisowni i interpunkcji” Stownika... PWN, ale również odwoływania się do szczegółowych zasad obowiązujących dla odmiany nazwisk hiszpańskich, włoskich, francuskich i węgierskich. Jednak coraz bardziej widoczna obecność katalońskich imion i nazwisk w mediach, literaturze oraz piśmiennictwie naukowym wymaga wprowadzenia ujednoliconego ich zapisu, a tym samym stworzenia odpowiednich reguł. Jak wspomniałam we wstępie do niniejszego artykułu, moim celem nie była analiza mechanizmów adaptacyjnych języka polskiego w odniesieniu do katalońskich nazw własnych, lecz próba uporządkowania ich form fleksyjnych w naszym języku. Mam nadzieję, że zaproponowane wyżej wzorce deklinacyjne przyczynią się do ograniczenia dowolności panującej w doborze owych form.

\section{Bibliografia}

BARTMIŃSCY, I. i J. (1978), Nazwiska obce w języku polskim, PWN, Warszawa. 
CALAFELLA MAJÓ, F. (2013), „Els noms del catalans del segle XXI”, Paratge. Quaderns d'estudis de genealogia, heràldica, sigil.lografia i nobiliària, 26, s. 159-176.

CIEŚLIKOWA, A. (2002), Mały słownik odmiany nazw własnych, Instytut Języka Polskiego PAN, Kraków.

Cognoms catalans (s.a.), „Estudi genètic dels cognoms catalans, valencian i balears", [on-line] http://cognoms.upf.edu/resultats/, 21.02.2021.

Gabinet d'Estudis Socials i Opinió Pública (2013), „Els noms de les dones a Catalunya", [on-line] https://gesop.net/ca/2013/04/26/breu-de-dades19-els-noms-de-les-dones-a-catalunya/, 21.02.2021.

Gabinet d'Estudis Socials i Opinió Pública (2013), „Els noms dels homes a Catalunya", [on-line] https://gesop.net/ca/2013/04/23/breu-de-dades18-els-noms-dels-homes-a-catalunya/, 21.02.2021.

GRZENIA, J. (2002), „Imiona i nazwiska hiszpańskie”, [on-line] https:// sjp.pwn.pl/poradnia/haslo/imiona-i-nazwiska-hiszpanskie;2126.html, 21.02.2021.

GRZENIA, J. (2011), „Odmiana imion na -e”, [on-line] https://sjp.pwn.pl/ poradnia/haslo/odmiana-imion-na-e; 12497.html, 21.02.2021.

GRZENIA, J. (2013), „Imiona portugalskie”, [on-line] https://sjp.pwn.pl/ poradnia/haslo/imiona-portugalskie;14244.html, 21.02.2021.

Institut d'Estadística de Catalunya (2019), „Noms més freqüents dels nadons. Per sexe", [on-line] https://www.idescat.cat/pub/?id=aec\&n=946, 21.02.2021.

Institut d'Estadística de Catalunya (s.a.), „Cognoms de la població”, [on-line] https://www.idescat.cat/cognoms/, 21.02.2021.

JADACKA, H. (2005), Kultura języka polskiego. Fleksja, słowotwórstwo, sktadnia, PWN, Warszawa.

KOMOROWSKI, A. (2019), „Hiszpania”, Twórczość, 3, [on-line] http://tworczosc.com.pl/artykul/hiszpania-2/, 21.02.2021.

MARKOWSKI, A. (2005), Kultura języka polskiego. Teoria. Zagadnienia leksykalne, PWN, Warszawa.

Noms del Món (s.a.), „Noms catalans”, [on-line] https://nomsdelmon.cat/ catalans/, 21.02.2021.

NOWAKOWSKA-GŁUSZAK, A. (2016), „Hiszpańskie imiona i nazwiska w tłumaczeniu poświadczonym na język polski”, Comparative 
Legilinguistics. International Journal for Legal Communication, 25, s. 79-94, https://doi.org/10.14746/c1.2016.25.05.

„Puigdemont złożył skargę w Komitecie Praw Człowieka”, Dziennik Gazeta Prawna 27.03.2018, [on-line] https://www.gazetaprawna.pl/wiadomosci/artykuly/1113928, puigdemont-zlozyl-skarge-w-komitecie-prawczlowieka-onz.html, 21.02.2021.

Societat Catalana de Genealogia (s.a.), ,Sobre noms i cognoms catalans”, [on-line] https://scgenealogia.cat/disciplines/genealogia/noms-i-cognomscatalans.html, 21.02.2021.

Societat d'Onomàstica (s.a.), [on-line] https://www.onomastica.cat/, 21.02.2021.

VV.AA. (s.a.), „Zasady pisowni i interpunkcji”, [on-line] https://sjp.pwn.pl/ zasady/Zasady-pisowni-i-interpunkcji;713485.html, 21.02.2021.

VV.AA. (2016), Gramàtica de la llengua catalana, Institut d'Estudis Catalans, Barcelona. 